DE LEGA LATA

Jurnal Ilmu Hukum

FAKULTAS HUKUM UMSU

\title{
PERLINDUNGAN HUKUM BAGI GURU DALAM MENJALANKAN TUGAS PENDIDIKAN DAN PENGAJARAN
}

\author{
Harisman \\ Fakultas Hukum Universitas Muhammadiyah Sumatera Utara \\ Jl. Kapt. Mukhtar Basri Nomor 3, Medan - Sumatera Utara, Indonesia \\ Email: harisman@umsu.ac.id
}

\begin{abstract}
Abstrak
Guru memiliki peran sentral dalam peningkatan potensi siswa sebagimana diamanahkan udangundang. Dalam pelaksanaan tugas kepropesiannya sering dituding melakukan perbuatan yang tidak terpuji terhadap siswanya. Akibatnya guru diperlakukan secara sewenang-wenang oleh berbagai pihak bahkan sampai adanya upaya kriminalisasi. Apabila kondisi seperti ini dibiarkan terus berlanjut akan dapat mengganggu tercapainya tujuan pendidikan nasional yang telah ditetapkan. Untuk menghidarinya perlu diteliti bagaimana perlindungan hukum bagi guru dalam pelaksanaan tugas utamanya. Untuk menjawabannya dilakukan penelitian hukum dengan menggunakan data sekunder yang bersumber dari kepustakaan berupa bahan hukum primer, bahan hukum sekunder, dan bahan hukum tersier. Data kepustakaan yang dikumpulkan dianalisis secara deskriptif dengan maksud untuk menggambarkan dan menguraikan apa yang menjadi objek dari penelitian. Berdasarkan pembahasan ditemukan bahwa guru harus memiliki kopetensi dan memahami akan hak dan kewajiban dalam menjalankan profesinya. Perlindungan Hukum bagi guru masih perlu dipertegas dengan kesepakatan kerjasama antara PGRI dan POLRI, dan Jurisprudensi sebagai pegangan bagi berbagai pihak dalam menangani permasalahan guru.
\end{abstract}

\section{Kata Kunci: Perlindungan Hukum, Guru, Pendidikan dan Pengajaran.}

\section{Abstract}

The teacher has a central role in increasing the potential of students as mandated by the law. In carrying out their professional tasks, they are often accused of committing acts that are not commendable to their students. As a result, teachers are treated arbitrarily by various parties even to the point of criminalization. If this condition is allowed to continue it will be able to disrupt the achievement of national education goals that have been set. To avoid this, it is necessary to examine how legal protection for teachers is in carrying out their main tasks. To answer this, legal research is conducted using secondary data sourced from the literature in the form of primary legal materials, secondary legal materials, and tertiary legal materials. Literature data were analyzed descriptively with a view to describe and elaborate on what became the object of research. Based on the discussion it was found that teachers must have competence and understand their rights and obligations in carrying out their profession. Legal protection for teachers still needs to be reinforced by the cooperation agreement between PGRI and the National Police, and Jurisprudence as a guide for various parties in dealing with teacher problems.

Keyword: The Protection of the Law, Teacher, Education and Teaching. PENDAHULUAN

Pasal 1 angka 1 Undang-Undang Nomor 14 Tahun 2005 tentang Guru dan Dosen menentukan Guru adalah pendidik profesional dengan tugas utama mendidik, mengajar, membimbing, mengarahkan, melatih, menilai, dan mengevaluasi peserta didik pada pendidikan 
Jurnal Ilmu Hukum

FAKULTAS HUKUM UMSU
Perlindungan Hukum Bagi...(Harisman) Volume 5 Nomor 1, Januari - Juni 2020, 79-93 DOI: https://doi.org/10.30596/dll.v5i1.3452

anak usia dini jalur pendidikan formal, pendidikan dasar, dan pendidikan menengah. Dalam rangka melaksanakan tugas profesionalnya, disamping dihadapkan pada kewajiban untuk senantiasa meningkatkan profesionalisme dan juga ada tantangan yang semakin kompleks seiring dengan perubahan cara pandang masyarakat yang secara sadar terpengaruh oleh doktrin perlindungan hukum terhadap anak, termasuk peserta didik. Namun di sisi lain, perlindungan hukum terhadap profesi guru juga harus diperhatikan.

Guru sebagai ujung tombak dalam satuan pendidikan memiliki tugas dan tanggung jawab tidak hanya sebatas meningkatkan pengetahuan semata termasuk pula sikap dan keterampilan. Berbagai macam metode dan bahkan penerapan sanksi disiplin diterapkan kepada peserta didik agar tujuan proses pembelajaran tercapai. Tidak jarang apa yang dilakukan guru mendapat tanggapan berbeda dari peserta didik dan bahkan orang tua/wali maupun masyarakat. Sampai ada sebagian tudingan mengangap beberapa metode yang digunakan dalam rangka pendisiplinan peserta didik oleh guru merupakan kekerasan yang tidak dapat ditolerir dan dikategorikan sebagai perbuatan yang dilarang bahkan dianggap sebagai perbuatan melawan hukum.

Menurut Data Internasional Center for Reseach on Women (ICRW) pada tahun 2015, sebanyak 84 persen siswa di Indonesia mengaku pernah mengalami kekerasan di sekolah. Sebanyak 45 Persen siswa dan 22 Persen siswi menyebutkan bahwa guru atau petugas sekolah merupakan pelaku kekerasan dan 75 persen siswa pernah melakukan kekerasan di sekolah.(Sukiman,2016) Banyaknya guru yang dituding melakukan kekerasan, yang pada akhirnya dikriminalisasikan sebagai konsekwensi berlakunya Undang-Undang Nomor 23 Tahun 2002 sebagaimana diubah terakhir dengan Undang-Undang Nomor 35 Tahun 2014 tentang Perlindungan Anak. Undang-undang ini seolah telah menjadi “jebakan batman”, menyandera, dan alat untuk melakukan kriminilasasi bagi guru. Hal ini pun tidak lepas dari pemaknaan HAM yang kebablasan pasca bergulirnya arus reformasi.(Mochamad Manshur)

Pada hal tindakan pendisiplinan yang dilakukan oleh Guru merupakan implikasi dari tugas dan tanggung jawab sebagai pendidik. Apalagi dimasa lampau dianggap biasa-biasa saja, kini dinilai melanggar HAM. Akibatnya guru seperti menghadapi dilema, disatu sisi guru harus menegakkan disiplin dan tata tertib sekolah, sementara disisi lain, khawatir dikriminalisasi oleh orang tua atau kelompok yang mengatasnamakan pembela anak di tuduh melakukan kekerasan terhadap anak.

Dampak dari dilema tersebut, akhirnya guru menjadi kurang tegas terhadap siswa yang kurang disiplin atau melanggar tata tertib sekolah. Siswa-siswa tidak disiplin tersebut dibiarkan saja, dari pada nantinya guru terkena masalah hukum. Ketidaktegasan guru berdampak terhadap semakin rendahnya wibawa guru di hadapan siswa, khususnya di kalangan siswa-siswi yang kurang disiplin. Peserta didik semakin seenaknya melanggar tata tertib sekolah, karena tidak akan dihukum. Guru akhirnya cari aman, tidak mau pusing dengan urusan sikap, perilaku, etika, dan sopan santun siswa (walau hatinya mungkin memberontak). Datang ke sekolah hanya mengajar, sampaikan materi sampai habis jam pelajaran, dan pulang.

Jika dibiarkan terus berlanjut, dapat menghilangkan kepercayaan guru dalam menjalankan profesinya sehingga akhirnya dapat menggangu tercapainya tujuan pendidikan nasional itu sendiri, yakni untuk berkembangnya potensi peserta didik agar menjadi manusia 
Jurnal Ilmu Hukum

FAKULTAS HUKUM UMSU
Perlindungan Hukum Bagi...(Harisman)

Volume 5 Nomor 1, Januari - Juni 2020, 79-93

DOI: https://doi.org/10.30596/dll.v5i1.3452

yang beriman dan bertakwa kepada Tuhan Yang Maha Esa, berakhlak mulia, sehat, berilmu, cakap, dan kreatif, mandiri, dan menjadi warga negara yang demokratis serta bertanggung jawab.

\section{METODE PENELITIAN}

Penulisan ini merupakan penelitian hukum yang bertujuan untuk mempelajari gejala hukum berkaitan dengan perlindungan hukum bagi guru dalam menjalankan tugas pendidikan dan pengajara. Soerjono Soekanto menyatakan penelitian hukum bertujuan untuk mempelajari satu atau beberapa gejala hukum tertentu, dengan jalan menganalisisnya (1986, h. 43). Pendekatan yang digunakan adalah yuridis normatif dengan menggunakan data sekuder yang bersumber dari kepustakaan berupa: bahan hukum primer, bahan hukum sekunder, dan bahan hukum tersier. Berbagai data yang diperoleh dan dikumpulkan kemudian dianalisis secara kualitatif dan dijabarkan secara desktriftif untuk mendapatkan jawaban atau penjelasan terhadap pengaturan hukum dan perlindungan hukum bagi guru dalam menjalankan tugas pendidikan dan pengajaran. Penelitian hukum normatif merupakan penelitian yang datanya bersumber pada data sekunder (Faisal, 2018, h. 145), oleh karena itu karena penelitian ini adalah normatif maka data yang digunakan adalah data sekunder. Bahan hukum sekunder meliputi penjelasan bahan hukum primer berupa doktrin para ahli yang ditemukan dalam buku, jurnal dan website (Rahmat Ramadhani, 2017, h. 142).

\section{PEMBAHASAAN DAN ANALISIS}

\section{Arti Penting Memahami Hakikat Pendidikan}

Makna pendidikan secara sederhana dapat diartikan sebagai usaha manusia untuk membina kepribadiannya sesuai dengan nilai-nilai didalam masyarakat dan kebudayaan. Pada hakikatnya pendidikan merupakan usaha manusia melestarikan hidupnya sebagimana ditentukan Pasal 1 angka 1 Undang-Undang Nomor 20 Tahun 2003 tentang Sistem Pendidikan Nasional. Oleh karena pendidikan dapat mengembangkan potensi diri setiap manusia berupa kemampuan yang berkaitan dengan sikap, pengetahuan dan keterampilan. Sebagaimana Asbin Pasaribu mengemukakan bahwa "pendidikan merupakan upaya mengembangkan potensipotensi manusiawi peserta didik baik potensi fisik potensi cipta, rasa, maupun karsanya, agar potensi itu menjadi nyata dan dapat berfungsi dalam perjalanan hidupnya." (2017, h. 24). Hal ini sesuai dengan apa yang menjadi tujuan pendidikan dalam rangka menyiapkan pribadi dalam keseimbangan, kesatuan, organis, harmonis, dinamis. guna mencapai tujuan hidup kemanusiaan.

Pendidikan merupakan suatu upaya yang terencana, yang dilakukan untuk mengembangkan potensi yang dimiliki oleh peserta didik. Potensi yang dimiliki oleh setiap peserta didik tentu berbeda-beda, yang nantinya adalah tugas seorang pendidik (guru) untuk mampu melihat dan mengasah potensi-potensi yang dimiliki peserta didiknya sehingga mampu berkembang menjadi manusia berguna bagi masyarakat, bangsa dan negara. Demikian pula secara tersirat terdapat makna bahwa pendidikan merupakan suatu prosen pembelajaran yang diselenggarakan dalam rangka pengembangan potensi peserta didik yang meliputi 3 (tiga) ranah, yaitu: pengetahuan, sikap dan keterampilan. 
DEIEGA LATA

Jurnal Ilmu Hukum

FAKULTAS HUKUM UMSU
Perlindungan Hukum Bagi...(Harisman)

Volume 5 Nomor 1, Januari - Juni 2020, 79-93 DOI: https://doi.org/10.30596/dll.v5i1.3452

Berkaitan dengan hal tersebut, setiap orang harus mampu memaknai arti penting dari hakekat pendidikan tersebut. Tanpa pemahaman yang baik dari semua pihak akan menggangu proses pembelajaran dan akhirnya tujuan pendidikan tidak tercapai. Apalagi memaknainya secara parsial antara, "mengajar" dan atau "mendidik".

Hal ini dapat berpengaruh terhadap cara pandang dalam melihat dan memahami kedudukan pendidik (guru) dalam menjalankan peran dan tugasnya. Meskipun beberapa orang mungkin terjebak dalam memaknai arti kedua istilah tersebut dalam pendidikan. Pada hal, terdapat perbedaan mendasar antara keduanya. Mengajar lebih ditekankan pada penguasaan pengetahuan tertentu, sedangkan mendidik lebih ditekankan pada pembentukan manusianya (penanaman sikap dan nilai-nilai).

Sejalan dengan itu Minal Ardi menyebutkan, bahwa tugas mendidik (transfer of values) berarti meneruskan dan mengembangkan nilai-nilai hidup dan kepribadian kepada para siswa. Sedangkan tugas mengajar (transfer of knowledge) berarti meneruskan dan mengembangkan ilmu pengetahuan dan teknologi, dengan lebih menekankan pada tugas dalam merencanakan dan melaksanakan pengajaran (Minal Ardi, 2013, h. 175).

Pendidikan harus dilihat sebagai suatu proses dan sekaligus sebagai tujuan. Melalui pandangan seperti ini, apa yang menjadi tujuan pendidikan dapat tercapai, sehingga kegiatan pendidikan bukan hanya sebagai kegiatan mengajar termasuk pula kegiatan mendidik.

\section{Kedudukan, Fungsi dan Peran Guru dalam Pendidikan.}

Penggunaan istilah "guru" telah digunakan dalam Undang-Undang Nomor 20 Tahun 2003 tentang Sistem Pendidikan Nasional, namun belum memberikan pengertian secara tegas, tetapi hanya baru sebatas mengkualifikasikannya sebagai tenaga kependidikan yang disebut dengan istilah "pendidik". Pengertian "guru" baru diberikan pengertiannya secara tegas pada Pasal 1 angka 1 Undang-Undang Nomor 14 Tahun 2014 tentang Guru dan Dosen dengan menyebutnya sebagai pendidik profesional. Istilah Guru menggambarkan pada suatu jabatan, posisi, dan profesi bagi seseorang yang mengabdikan dirinya dalam bidang pendidikan melalui interaksi edukatif secara terpola, formal, dan sistematis (M.Shabri. U, 2015, h. 221).

Guru merupakan profesi tua dan bahkan profesi yang mulia dan terhormat di masyarakat (Harun, 2016, h. 78). Guru dihormati oleh masyarakat karena wibawanya, sehingga masyarakat tidak meragukan figur guru. Masyarakat percaya bahwa guru diharapkan mampu untuk mendidik dan membentuk kepribadian dan intelektual anak didik dengan baik. Bahkan guru dipandang sebagai pengemban tugas kemanusiaan yang dianggap mampu untuk mencerdaskan kehidupan bangsa dan membangun watak, budaya dan mengantarkan bangsa pada kehidupan masyarakat yang maju adil dan makmur serta beradab (Harun). Demikian pula guru dapat dipandang sebagai profesi yang luhur, mulia, dan bermartabat (Ramlan, 2018, h. 1).

Berdasarkan Pasal 4 Undang-Undang Nomor 14 Tahun 2005 Tentang Guru dan Dosen, secara tegas menentukan kedudukan, fungsi dan peran guru dalam bidang pendidikan. Guru memiliki kedudukan sebagai tenaga profesional yang memiliki fungsi untuk meningkatkan martabat dan berperan sebagai agen pembelajaran yang berfungsi untuk meningkatkan mutu pendidikan nasional. 
DEIEGA LATA

Jurnal Ilmu Hukum

FAKULTAS HUKUM UMSU
Perlindungan Hukum Bagi...(Harisman)

Volume 5 Nomor 1, Januari - Juni 2020, 79-93 DOI: https://doi.org/10.30596/dll.v5i1.3452

Kedudukan Guru sebagaimana termuat pada Pasal 1 angka 1 Undang-Undang Nomor 14 Tahun 2005 merupakan tenaga profesional memiliki tugas utama mendidik, mengajar, membimbing, mengarahkan, melatih, menilai, dan mengevaluasi peserta didik. Guru sebagai tenaga profesional dalam menjalankan tugas utamanya di bidang pendidikan bertujuan untuk melaksanakan sistem pendidikan nasional dan mewujudkan tujuan pendidikan nasional, yaitu berkembangnya potensi peserta didik agar menjadi manusia yang beriman dan bertakwa kepada Tuhan Yang Maha Esa, berakhlak mulia, sehat, berilmu, cakap, kreatif, mandiri, serta menjadi warga negara yang demokratis dan bertanggung jawab. Hal ini sejalan dengan tujuan pendidikan nasional sebagaimana telah ditetapkan pada Pasal 3 Undang-Undang Nomor 20 Tahun 2003 Tentang Sistem Pendidikan Nasional.

Melihat pada tugas utama guru dan tujuan pendidikan nasional sebagaimana telah ditetapkan dalam peraturan perundangan di atas, secara tersurat dan tersirat menggambar bahwa guru dalam pelaksanaan pendidikan memiliki peran bukan saja sebagai "pengajar" dalam rangka mengembangkan ilmu pengetahuan semata (hardskill), tetapi berperan pula sebagai "pendidik" dalam rangka membentu sikap dan karakter (soft skill) dari anak didik. Endang Komara menyatakan, bahwa guru bukan saja berperan sebagai pelaksana jalannya pendidikan dan pembelajaran, tetapi guru dapat pula membentuk karakter muridnya (Endang Komara, 2016, h.153). Hal ini sesuai dengan apa yang menjadi arti dan makna dari pendidikan itu sendiri, yakni mengajar dan mendidik. Untuk itu Guru memiliki fungsi dan peran untuk mengembangkan potensi kemampuan anak didik yang meliputi: pengetahuan, sikap dan keterampilan sebagaimana telah di uraikan pada sub pokok bahasan di atas.

Guru dapat pula bertindak menjadi motivator bagi anak didik. Oleh karena seorang guru harus mampu memberikan motivasi kepada para siswa agar mau dan mampu belajar dengan tekun dan giat sehingga siswa benar-benar mampu meraih hasil dalam belajar (Mavianti, 2019, h. 56) Elly Manizar menyebutkan peran seorang guru bukan hanya semata-mata mentransfer ilmu mata pelajarannya kepada siswa, tetapi, guru juga sebagai motivator bagi siswa agar memiliki prestasi dalam belajar (2015, h. 173). Pemberian motivasi oleh guru bagi siswa dapat menjadi faktor yang dominan untuk keberhasilan tercapai atau tidaknya tujuan pembelajaran. Dengan motivasi mendorong timbulnya tingkah laku dan mempengaruhi serta mengubah tingkah laku siswa. Ada 3 (tiga) fungsi motivasi, yaitu (Sudirman, 2008, h. 60):

1. Mendorong timbulnya tingkah laku atau perbuatan; Tanpa motivasi tidak akan timbul suatu perbuatan. Motivasi dalam hal ini merupakan motor penggerak dari setiap kegiatan yang akan dikerjakan.

2. Motivasi berfungsi sebagai pengarah; Artinya motivasi mengarahkan perubahan untuk mencapai yang diinginkan. Dengan demikian, motivasi dapat memberikan arah dan kegiatan yang harus dikerjakan sesuai dengan rumusan tujuannya.

3. Motivasi berfungsi sebagai penggerak; Artinya mengerakkan tingkah laku seseorang. Selain itu, motivasi belajar berfungsi sebagai pendorong usaha dan pencapaian prestasi.

Peran guru sebagai motivator berarti guru sebagai pendorong siswa dalam rangka meningkatkan kegairahan dan pengembangan kegiatan belajar siswa (Elly Menizar, 2015, h. 179) Winkel menyebutkan, "motivasi belajar merupakan keseluruhan daya penggerak psikis di dalam diri siswa yang menimbulkan kegiatan belajar, menjamin kelangsungan kegiatan belajar 
DE LEGA LATA

Jurnal Ilmu Hukum

FAKULTAS HUKUM UMSU
Perlindungan Hukum Bagi...(Harisman) Volume 5 Nomor 1, Januari - Juni 2020, 79-93 DOI: https://doi.org/10.30596/dll.v5i1.3452

dan memberikan arah pada kegiatan belajar itu demi mencapai suatu tujuan." (Winkel, 2005, h. 87). Guru berperan sebagai motivator hendaknya memiliki sikap yang bersifat terbuka dan mau membantu anak didik agar mampu memahami dan memanfaatkan potensi yang ada pada dirinya secara optimal (Elly Menizar, 2015, h. 183).

Seiring dengan pergeseran makna pembelajaran dari pembelajaran yang berorientasi kepada guru (teacher oriented) ke pembelajaran yang berorientasi kepada siswa (student oriented), dan demikian pula (perkembangan teknologi informasi saat ini, peran guru dalam proses pembelajaran pun mengalami pergeseran (M.Shabhir.U, 2015, h.22). Guru tidak lagi sekedar bertindak sebagai penyaji informasi, tetapi harus mampu menjadi motivator, fasilitator dan pembimbing yang lebih banyak memberikan kesempatan kepada siswa untuk mencari dan mengolah sendiri informasi (Uno.Hamza.B, 2009, h. 16-17).

Peran guru selain dari pada penyaji/penyampai ilmu pengetahuan, motivator, fasilitator dan pembimbing yang oleh undang-undang diberikan pula peran untuk meningkatkan disiplin siswa berupa pemberian sanksi/disiplin. Adanya kewenangan guru dalam penerapan sanksi bagi siswa didasarkan pada Pasal 14 ayat (1) huruf f Undang-Undang Nomor 14 Tahun 2005 Tentang Guru dan Dosen, yang memberikan hak kebebasan bagi guru untuk memberikan sanksi kepada siswa, sesuai dengan kaidah pendidikan, kode etik guru, dan peraturan perundangundangan.

Hak kebebasan guru memberikan sanksi sebagai bentuk peningkatan disiplin dalam pembelajaran sebagaimana ditetapkan Pasal 39 ayat (1) Peraturan Pemerintah Nomor 74 Tahun 2008 Tentang Guru, diterapkan terhadap siswa yang melanggar norma agama, norma kesusilaan, norma kesopanan, peraturan tertulis maupun tidak tertulis yang ditetapkan guru, peraturan tingkat satuan pendidika, dan peraturam perundang-undagan dalam proses pembelajaran yang berada dibawah kewenangannya. Selanjutnya berdasarkan ayat (2) nya dinyatakan penerapan sanksi sebagai upaya pendisiplinan siswa dapat berupa teguran dan/atau peringatan, baik lisan maupun tulisan, serta hukuman yang bersifat mendidik sesuai dengan kaedah pendidikan, kode etik guru dan peraturan perundang-undangan.

Melihat begitu strategisnya peran Guru sebagai pelaksana pendidikan dan pengajaran diberikan kewajiban sebagaimana di atur pada Pasal 20 Undang-Undang Nomor 14 Tahun 2005 sebagai berikut:

a. Merencanakan pembelajaran, melaksanakan proses pembelajaran yang bermutu, serta menilai dan mengevaluasi hasil pembelajaran;

b. Meningkatkan dan mengembangkan kualifikasi akadernik dan kompetensi secara berkelanjutan sejalan dengan perkembangan ilmu pengetahuan, teknologi, dan seni;

c. Bertindak objektif dan tidak diskriminatif atas dasar pertimbangan jenis kelamin, agama, suku, ras, dan kondisi fisik tertentu, atau latar belakang keluarga, dan status sosial ekonomi peserta didik dalam pembelajaran;

d. Menjunjung tinggi peraturan perundang-undangan, hukum, dan kode etik guru, serta nilainilai agama dan etika; dan

e. Memelihara dan memupuk persatuan dan kesatuan bangsa. 
DE LEGA LATA

Jurnal Ilmu Hukum

FAKULTAS HUKUM UMSU
Perlindungan Hukum Bagi...(Harisman)

Volume 5 Nomor 1, Januari - Juni 2020, 79-93

DOI: https://doi.org/10.30596/dll.v5i1.3452

\section{Pengaturan Hukum Bagi Guru Dalam Melaksanakan Tugas Utama Pengajaran dan Pendidikan Terhadap Peserta Didik.}

Keberhasilan pencapaian tujuan pendidikan nasional tidak terlepas dari kedudukan dan peran guru sebagai tenaga profesional yang mempunyai tanggungjawab untuk mengembangkan potensi siswa. Ketut Novi Ariawati menyebutkan, "untuk dapat mencapai tujuan pendidikan nasional, sangat diperlukan guru profesional" (Ketut Novi Ariawati, 2017, h. 2). Mengacu pada defenisi profesional yang ditetapkan Pasal 1 angka 4 Undang-Undang Nomor 14 Tahun 2005 Tentang Guru dan Dosen, maka guru profesional menunjukkan pada kemampuan yang dimiliki guru berupa keahlian, kemahiran dan kecakapan dalam melaksanakan pengajaran dan pendidikan. Guru profesional adalah guru yang memiliki kompetensi yang dipersyaratkan untuk melakukan tugas pendidikan dan pengajaran. Guru profesional adalah orang yang memiliki kemampuan dan keahlian khusus dalam bidang keguruan sehingga ia mampu melaksanakan tugas dan fungsinya sebagai guru dengan kemampuan (Kunandar, 2009, h.4647).

Guru sebagai pendidik profesional dalam melaksanakan keprofesionalannya akan berhadapan langsung dengan siswa.(Harun, h.176) Guru dan siswa dipadang sebagai subjek dalam sistem pendidikan, yang tanpanya pendidikan tidak akan bermakna apa pun.

Begitu pula pendidikan harus dilihat sebagai suatu sistem yang mengambarkan adanya hubungan antara guru dan siswa. Guru dan siswa di sekolah hanya merupakan bagian kecil di antara komponen yang ada dalam sistem pendidikan seperti: tujuan pendidikan, alat pendidikan, dan lingkungan pendidikan. Ini berarti pendidikan dilihat sebagai suatu sistem yang tergabung dari beberapa komponen pendidikan yang satu dengan yang lain saling berhubungan (Sulaiman Saat, 2015, h. 1).

Adanya hubungan guru dan siswa yang dilihat sebagai bagian dari komponen sistem pendidikan bukan berarti menunjukkan pada tinggi rendahnya kedudukan, tetapi melihat akan perannya masing-masing yang saling berhubungan. Guru memiliki tugas utama untuk melaksanakan pendidikan dan pengajaran, sedangkan peserta didik bertugas untuk belajar dalam rangka menimba ilmu pengetahuan dan mengembangkan pontensi dirinya.

Bukan berarti guru lebih penting dibandingkan peserta didik. Guru hendaknya memperlakukan peserta didik sebagai subjek dan bukan menempatkannya sebagai objek dalam pendidikan. Artinya peserta didik harus diperlakukan selayaknya sebagai manusia yang memiliki hak dan kewajiban, dan bukan diperlakukan layaknya sebagai benda.yang bisa diperlakukan secara sewenang-wenang. Untuk itu meskipun peserta didik terkadang memiliki sikap perbuatan dan tindakan yang terkadang dianggap tidak terpuji yang tidak sesuai dengan nilai-nilain atau aturan-aturan yang berlaku seperti agama, kesopanan, moral, dan hukum, guru harus memperlakukannya selayaknya sebagai manusia. Guru sebagai pendidik professional dalam menjalankan keprofesionalisnya dituntut untuk memiliki suatu kompetensi. M. Sabir U menyebutkan "guru harus memiliki dan menguasai kompetensinya dan sekaligus mengetahui hak dan kewajibannya sehingga ia menjadi sosok guru yang betul-betul profesional (M.Sabir U, 2015, h. 223).

Undang-Undang Nomor 14 Tahun 2005 Tentang Guru dan Dosen, mengisyaratkan untuk menjadi guru yang profesional diwajibkan memiliki kompetensi. Kompetensi adalah 
Jurnal Ilmu Hukum

FAKULTAS HUKUM UMSU
Perlindungan Hukum Bagi...(Harisman)

Volume 5 Nomor 1, Januari - Juni 2020, 79-93 DOI: https://doi.org/10.30596/dll.v5i1.34.52

seperangkat pengetahuan, keterampilan, dan perilaku yang harus dimiliki, dihayati, dan dikuasai oleh guru atau dosen dalam melaksanakan tugas keprofesionalan. Guru tanpa kompetensi tidak akan dapat memahami akan kedudukannya, fungsi, peran dan tugasnya dalam melaksanakan pendidikan sehingga sulit untuk mencapai apa yang menjadi tujuan pendidikan nasional yang dicita-citakan sebagaimana telah ditetapkan undang-undang sistem pendidikan nasional.

Adapun kompetensi yang harus dimiliki untuk menjadi guru yang profesional, yaitu: kompetensi pedagogik, kompetensi kepribadian, kompetensi sosial dan kompetensi profesional yang diperoleh melalui pendidikan profesi. Dalam Penjelasan Undang-Undang Nomor 14 Tahun 2005 Tentang Guru dan Dosen dijelaskan bahwa kompetensi pedagogik adalah kemampuan mengelola pembelajaran peserta didik, sedangkan kompetensi kepribadian adalah kemampuan kepribadian yang mantap, berakhlak mulia, arif, dan berwibawa serta menjadi teladan bagi peserta didik. Selanjutnya dikemukakan pula pengertian kompetensi sosial adalah kemampuan guru untuk berkomunikasi dan berinteraksi secara efektif dan efisien dengan peserta didik, sesama guru, orang tua/wali peserta didik, dan masyarakat sekitar, dan kompetensi profesional adalah kemampuan penguasaan materi pelajaran secara luas dan mendalam.

Berbagai kompetensi yang harus dimiliki oleh guru sebagaimana ditetapkan Pasal 3 ayat (3) Peraturan Pemerintah Nomor 74 Tahun 2008 Tentang Guru bersifat holistik (menyeluruh) dan merupakan standart minimal. Yusutria menyatakan dalam menjalankan kewenangan profesionalnya, guru dituntut memiliki keanekaragaman kecakapan (competencies) psikologis yang meliputi: (1) kompetensi kognitif (kecakapan ranah cipta); kompetensi afektif (kecakapan ranah rasa); kecakapan psikomotor (kecakapan ranahkarsa) (Yusutria, 2017, h. 41-42). Guru yang memiliki kompetensi akan mudah untuk meningkatkan potensi peserta didik dengan menempatkannya sebagai subjek pendidikan. Begitu pentinggnya guru memiliki kompetensi sebagai salah satu prasyarat untuk terselenggaranya pendidikan sebagai upaya untuk meningkatkan potensi peserta didik.

Guru sebagai pendidik profesional selain dipersyaratkan memiliki kompetensi, dalam menjalankan tugas utamanya diberikan pula suatu hak dan kewajiban sebagaimana di atur dalam undang-undang. Berbagai hak dan kewajiban yang telah ditetapkan dijadikan pedoman bagi guru dalam melaksanakan tugas utamanya. Ketentuan yang digunakan sebagai pedoman guru dalam melaksanakan tugasnya dengan mengacu pada peraturan perundang-undangan yang antara lain sebagai berikut:

a. Undang-Undang Nomor 20 Tahun 2003 Tentang Sistem Pendidikan Nasional:

b. Undang-Undang Nomor 35 Tahun 2014 tetang Perubahan Atas Undang-Undang Nomor 23 Tahun 2002 Tentang Perlindungan Anak;

c. Undang-Undang Nomor 14 Tahun 2005 Tentang Guru dan Dosen;

d. Peraturan Pemerintah Nomor 19 Tahun 2017 Tentang Perubahan Atas Peraturan Pemerintah Nomor 74 Tahun 2008 Tentang Guru.

e. Kode Etik Guru.

Dimasukkannya undang-undang perlidungan anak sebagai pedoman bagi guru dalam melaksanakan tugas utamanya, disebababkan guru sebagai pendidik profesional pada jenjang 
DE LEGA LATA

Jurnal Ilmu Hukum

FAKULTAS HUKUM UMSU
Perlindungan Hukum Bagi...(Harisman)

Volume 5 Nomor 1, Januari - Juni 2020, 79-93 DOI: https://doi.org/10.30596/dll.v5i1.3452

pendidikan anak usia dini jalur pendidikan formal, pendidikan dasar, dan pendidikan menengah. Pada jenjang ini peserta didik masih berstatus sebagai anak.

Adapun pedoman bagi guru dalam menjalankan tugas utamanya dengan memperhatikan dan mempertimbangkan hal-hal sebagai berikut:

a. Setiap anak dalam satuan pendidikan wajib mendapatkan perlindungan dari tindakan kekerasan fisik, psikis, kejahatan seksual dan kejahatan lainnya yang dilakukan oleh pendidik;

b. Bertindak objektif dan tidak diskriminatif atas dasar pertimbangan jenis kelamin, agama, suku, ras, dan kondisi fisik tertentu, atau latar belakang keluarga, dan status sosial ekonomi peserta didik dalam pembelajaran;

c. Guru memiliki kebebasan dalam memberikan penilaian, ikut menentukan kelulusan, peghargaan, dan/atau sanksi kepada peserta didikk sesuai dengan kaedah pendidikan, kode etik guru dan peraturan perundang-undangan;

d. Guru memiliki kebebasan memberikan sanksi kepada peserta didiknya yang melanggar agama, norma kesusilaan, norma kesopanan, peraturan tertulis maupun tidak tertulis yang ditetapkan guru, peraturan tingkat satuan pendidikan, dan peraturan perundang-undangan dalam proses pembelajaran di bawah kewenanganya;

e. Penerapan sanksi berupa teguran dan/atau peringatan, baik lisan mauun tulisan, serta hukuman yang bersifat mendidik sesuai dengan kaedah pendidikan, kode etik guru dan peraturan perundang-undangan; dan

f. Menjunjung tinggi peraturan perundang-undangan, hukum, dan kode etik guru, serta nilainilai agama dan etika;

Berbagai pedoman di atas dijadikan sebagai dasar sikap dan prilaku bertindak bagi guru dalam mendukung kompetensi yang dimilikinya dan melaksanakan tugas utamanya. Di dalam Undang-Undang Nomor 14 Tahun 2005 dan Peraturan Pemerintah Nomor 74 Tahun 2008, ketentuan-ketentuan pedoman di atas ditetapkan dan dijabarkan menjadi bagian dari hak dan kewajiban guru dalam menjalankan tugas utamnya, yakni mendidik dan mengajar. Kompetensi, dan hak dan kewajiban guru sebagaimana ditetapkan oleh undang-undang dijadikan sebagai pegangan bagi guru dalam melaksanakan keprofesiannya.

Guru selain dituntut untuk memiliki persyaratan kompetensi dan memenuhi hak dan kewajiban yang ditetapkan oleh undang-undang, untuk melaksanakan tugas dan tanggungjawabannya dalam pendidikan dan pengajaran diberikan pula beban kerja. Berdasarkan Pasal 52 ayat (1) Peraturan Pemerintah Nomor 74 Tahun 2008, beban kerja guru dalam melaksanakan pendidikan dan pengajaran meliputi: kegiatan merencanakan pembelajaran, melaksanakan pembelajaran, menilai hasil pembelajaran, membimbing dan melatih peserta didik, dan melaksanakan tugas tambahan yang melekat pada pelaksanaan kegiatan pokok.

Berdasarkan uraian di atas, kompetensi guru, hak dan kewajiban guru, dan beban kerja guru merupakan komponen yang dijadikan sebagai pedoman bagi guru dalam melaksanakan pendidikan dan pengajaran. Kompetensi guru, dan hak dan kewajiban ditujukan untuk mempengaruhi terhadap sikap-prilaku dan perbuatan guru, sedangkan beban kerja merupakan 
DE LEGA LATA

Jurnal Ilmu Hukum

FAKULTAS HUKUM UMSU
Perlindungan Hukum Bagi...(Harisman) Volume 5 Nomor 1, Januari - Juni 2020, 79-93 DOI: https://doi.org/10.30596/dll.v5i1.3452

tugas pekerjaan yang dipersiapakan guru. Keberhasilan guru dalam melaksanakan pendidikan dan pengajaran dipengaruhi pula oleh komponen-komponen tersebut.

\section{Perlindungan Hukum Bagi Guru dalam Menjalankan Tugas Pendidikan dan Pengajaran.}

Profesi guru merupakan pekerjaan mulia yang sudah sewajarnyalah diberikan perlindungan. Perlindungan adalah pemberian jaminan atas keamanan, ketentraman, kesejahteraan dan kedamian dari perlindungan atas segala bahaya yang mengancam pihak yang dilindungi (Fajaruddin, 2014, h. 31). Perlindungan bagi guru dalam menjalankan tugas keprofesiannya merupakan perintah undang-undang (Endang Komara, 2016, h.152). Guru secara normatif, memang telah mendapatkan perlindungan, sebagaimana ketentuan Pasal 39 Undang-Undang Nomor 14 Tahun 2005 ayat (1): "Pemerintah, pemerintah daerah, masyarakat, organisasi profesi, dan/atau satuan pendidikan wajib memberikan perlindungan terhadap guru dalam pelaksanaan tugas". Rumusan undang-undang tersebut telah memberikan dan mewajibkan adanya perlindungan kepada guru dalam tugasnya.(Harun, h.76) Perlindungan guru dalam ayat (2) pasal ini meliputi: perlindungan hukum, perlindungan profesi, dan perlindungan keselamatan dan kesehatan kerja. Disamping itu guru berhak pula memperoleh perlindungan dalam pelaksanaan tugas dan hak kekayaan intelektual sebagaimana di atur Pasal 14 ayat (1) huruf c undang-undang ini.

Meskipun guru secara normatif diberikan perlindungan, namun hingga saat ini belum ada peraturan pelaksana yang secara teknis operasional mengatur berbagai macam perlindungan terhadap guru, termasuk perlindungan hukumnya (Leni Dwi Nurmala, 2018, h.71). Perlindungan hukum sebagaimana Pasal 39 ayat (3) Undang-Undang Nomor 14 Tahun 2005 Tentang Guru hanya menentukan: "Perlindungan hukum sebagaimana dimaksud pada ayat (2) mencakup perlindungan hukum terhadap tindak kekerasan, ancaman, perlakuan diskriminatif, intimidasi, atau perlakuan tidak adil dari pihak peserta didik, orang tua peserta didik, masyarakat, birokrasi, atau pihak lain.” Akibatnya, tidak jarang guru diadukan secara hukum dan bahkan dikriminalisasi oleh berbagai pihak antara lain: peserta didik (siswa), orang tua atau wali siswa, dan masyarakat mengatasnamakan pendidikan.

Persoalan seperti ini timbul sebagai akibat dari adanya perbedaan pendapat atau penafsiran terhadap perbuatan atau tindakan yang dilakukan oleh guru terhadap peserta didik dalam pelaksanaan pendidikan dan pengajaran. Seperti adanya perbedaan penafsiran dan pemahaman atas penerapan sanksi sebagai bentuk pendisiplinan yang dilakukan guru terhadap peserta didik. Pada hal penerapan sanksi merupakan hak kebebasan yang diberikan undangundang kepada guru sebagai bagian dari pelaksanaan pendidikan dan pengajaran. Pasal 14 ayat (1) huruf f Undang-Undang Nomor 14 Tahun 2005 Tentang Guru dan Dosen, menentukan: "guru berhak memiliki kebebasan dalam memberikan penilaian dan ikut menentukan kelulusan, penghargaan, dan/ atau sanksi kepada peserta didik sesuai dengan kaidah pendidikan, kode etik guru, dan peraturan perundang-undangan”.

Perbedaan pendapat atau penafsiran terhadap cara pemberian sanksi yang dilakukan guru dalam upaya pendisiplinan peserta didik, dipengaruhi oleh perkembangan hukum

perlindungan anak. Pasal 9 ayat (1a) Undang-Undang Nomor 35 Tahun 2014 Tentang Perubahan Atas Undang-Undang Nomor 23 Tahun 2002 Tentang Perlindungan Anak 
DE LEGA LATA

Jurnal Ilmu Hukum

FAKULTAS HUKUM UMSU
Perlindungan Hukum Bagi...(Harisman)

Volume 5 Nomor 1, Januari - Juni 2020, 79-93 DOI: https://doi.org/10.30596/dll.v5i1.3452

menentukan: "Setiap Anak berhak mendapatkan perlindungan disatuan pendidikan dari kejahatan seksual dan Kekerasan yang dilakukan oleh pendidik, tenaga kependidikan, sesama peserta didik, dan/atau pihak lain". Selanjutnya Pasal 54 ayat (1) undang-undang yang sama, "Anak di dalam dan di lingkungan satuan pendidikan wajib mendapatkan perlindungan dari tindak kekerasan fisik, psikis, kejahatan seksual, dan kejahatan lainnya yang dilakukan oleh pendidik, tenaga kependidikan, sesama peserta didik, dan/atau pihak lain”.

Ketentuan pasal tersebut sering dijadikan sabagai dasar untuk menyatakan tindakan disiplin berupa saksi yang diterapkan oleh guru terhadap peserta didik dianggap sebagai perbuatan kekerasan. Meskipun undang-undang perlindungan anak memberikan defenisi "kekerasan adalah setiap perbuatan terhadap Anak yang berakibat timbulnya kesengsaraan atau penderitaan secara fisik, psikis, seksual, dan/atau penelantaran, termasuk ancaman untuk melakukan perbuatan, pemaksaan, atau perampasan kemerdekaan secara melawan hukum". Apabila dilihat tidak adanya ukuran yang jelas diberikan oleh undang-undang terhadap kekerasan sehingga pengimplementasiannya menimbulkan perbedaan pendapat atau penafsiran dalam penerapannya khususnya di bidang pendidikan. Begitu pula adanya ketentuan yang mewajibkan guru dalam pelaksanan tugas keprofesiannya bertindak objektif dan tidak diskrimatif sebagaimana di atur Pasal 20 huruf c Undang-Undang Nomor 14 Tahun 2008.

Apabila hal ini dibiarkan terus berlanjut dikhawatirkan perlindungan hukum terhadap guru dari berbagai bentuk sebagaimana ditentukan dalam Pasal 39 ayat (2) Undang-Undang Nomor 14 Tahun 2015 tidak akan dapat terwujud. Perlindungan hukum bagi guru dalam pelaksaaan tugas keprofesiannya mencakup perlindungan hukum terhadap tindak kekerasan, ancaman, perlakuan diskriminatif, intimidasi, atau perlakuann tidak adil dari pihak peserta didik, orang tua peserta didik, masyarakat, birokrasi, atau pihak lain. Philipus M. Hadjon berpendapat bahwa Perlindungan Hukum adalah perlindungan akan harkat dan martabat, serta pengakuan terhadaphak-hak asasi manusia yang dimiliki oleh subyek hukum berdasarkan ketentuan hukum dari kesewenangan (Leni Dwi Nurmala, 2018, h. 68).

Beberapa upaya yang dilakukan sebagai upaya perlindungan hukum bagi guru dalam menjalankan tugas kepropesiannya sebagai berikut:

a. Membentuk norma perlindungan hukum bagi guru dalam peraturan perundang di bidang pendidikan dan kode etik;

b. Mengadakan kerjasama atara lembaga profesi guru dan Kepolisian beserta penegak hukum lainnya dengan membentuk Momerandum of Understending untuk menangani dan menyelesaikan permasalahan guru dalam menjalankan tugas kepropesiannya ; dan

c. Menerapkan Jurisprudensi sebagai dasar menghilangkan perbedaan pendapat atau penafsiran terhadap perbuatan guru dalam menjalankan tugas utamanya.

Peraturan perundangan di bidang pendidikan memuat norma hukum sebagai upaya perlindungan guru dalam pelaksanaan tugas keprofesiannya. Ketentuan hukum perlindungan hukum bagi guru dapat ditemukan pada Pasal 39 Undang-Undang Nomor 14 Tahun 2005 Tentang Guru dan Dosen, dan Pasal 40 Peraturan Pemerintah Nomor 74 Tahun 2008 tentang Guru. Perlindungan hukum bagi guru dimaksudkan sebagai upaya memberikan rasa aman dan jaminan keselamatan dalam pelaksanaan tugas keprofesiannya. Diaturnya perlindungan hukum bagi guru melalui pembentukan perudang-undangan di bidang pendidikan bukan berarti sudah 
Jurnal Ilmu Hukum

FAKULTAS HUKUM UMSU
Perlindungan Hukum Bagi...(Harisman) Volume 5 Nomor 1, Januari - Juni 2020, 79-93 DOI: https://doi.org/10.30596/dll.v5i1.3452

memadai. Masih ditemukan beberapa kendala dalam pelaksanaannya sebagaimana diuraikan di atas seperti: timbulnya beberapa penafsiran terhadap norma-norma hukum yang di atur sebagai pengaruh dari berkembangnya konsep hukum perlindungan anak.

Mengingat masih ditemukannya kendala penerapan perlindungan hukum bagi guru dalam perundang-undangan, diadakan Kerjasama melalui pembentukan Nota Kesepahaman (Memorondum of Understanding/MoU) anatra Lembaga Profesi Guru, yakni: Persatuan Guru Republik Indonesia (PGRI) dengan Kepolisian Republik Indonesia (POLRI) Nomor: B/53/XII/2012, Nomor: 1003/UM/PB/XX/2012 Tentang Mekanisme Penanganan Perkara Dan Pengamanan Terhadap Profesi Guru. Pembentukan MoU dilatarbelakangi oleh perlindungan hukum dan keamanan bagi guru dalam menjalankan profesi sampai sekarang belum ada rumusan atau pedoman kerja yang komprehensif sehingga terjadi kesimpangsiuran dan kesalahpahaman antara Guru dan POLRI. MoU ini melakukan penggolongan perbuatan guru atas: perbuatan guru yang tidak sengaja, perbuatan guru yang rawan menimbulkan tindak pidana, perbuatan yang disengaja, dan perbuatan guru dengan niat melakukan tindak pidana. Dengan pengelompokan ini dapat dijadikan pedoman dalam menentukan apakah perbuatan guru termasuk perbuatan pidana. Pengelompokan ini bertujuan untuk menyatukan pandangan terhadap perbuatan guru ketikan melaksanakan tugas keprofesiannya."

Perlindungan hukum bagi guru dapat pula mengacu pada penerapan jurisprudensi. Berdasarkan Putusan Mahkamah Agung Tanggal 6 Mei 2013 dalam Kasus pendisiplinan 4 (empat) siswa berambut gondrong di Majalengka oleh guru dengan mencukur dituntut melanggar Pasal 77 huruf a dan Pasal 80 ayat (1) Undang-Undang Perlindungan Anak, dan Pasal 335 ayat (1) KUH Pidana tentang Perbuatan yang tidak menyenangkan bahwa guru tidak bisa dipidanakan saat menjalankan profesinya melakukan tindakan pendisiplinan terhadap siswa.

Selain itu dibutuhkannya peraturan internal sekolah yang dibuat bersama-sama antara Pimpinan Sekolah, Guru, dan Orang tua/wali murit untuk dijadikan standar dalam penegakan disiplin bagi peserta didik. Dengan peraturan internal sekolah seperti ini, guru dalam menjalankan tugas dan profesinya mendapatkan perlindungan hukum. Oleh karena guru sudah memiliki patokan atau ukuran yang jelas sanksi apa yang akan dijatuhkan sebagai bentuk penegakan disiplin.

Berdasarkan uraian di atas, perlindungan hukum bagi guru ditujukan pada pembentukan sikap, tidakan dan atau perbuatan dari guru dalam pelaksanaan tugas keprofesiannya ketika berhadapan dengan peserta didik. Apa yang dilakukan oleh guru dalam pelaksanaan tugas profesinya tidak selalau dianggap sebagai perbutan melawan hukum yang pada akhirnya dikriminalisasikan.

\section{KESIMPULAN}

Guru merupakan pendidik profesional dalam pelaksanaan tugas kepropesionalannya wajib memiliki kompetensi. Guru harus mengetahui dan memahami kompetensi yang wajib dimilikinya sebagaimana ditentukan undang-undang. Guru melaksanakan tugas keprofesiannya harus memahami akan hak dan kewajibannya. Dengan memahami kompetensi, dan hak dan kewajibannya, guru dapat terhindar dari berbagai permasalahan dalam pelaksanaan tugas profesinya. Guru dalam pelaksanaan tugas keprofesiannya mendapatkan perlindugan Hukum. 
Perlindungan Hukum bagi Guru dapat berupa: penetapan norma perlindungan hukum, Kerjasama PGRI dan POLRI berkaitan dengan permasalahan hukum guru, dan jurisprudensi.

\section{SARAN}

Penyelesaian masalah guru dalam menjalankan tugas pendidikan dan pengajaran hendaknya lebih mengutamakan pendekatan nonlitigasi dari pada pendekatan litigasi yang dijadikan ultimum remidium sebagai salah satu bentuk perlindungan hukum yang dapat diberikan. Hal ini didasarkan pertimbangan bahwa guru dihadapkan pada 2 (dua) pilihan, yaitu disatu sisi memiliki tanggung jawab untuk mendidik dan mengajar, dan disisi lain dituntut untuk tidak melakukan perbuatan yang dilarang sebagaimana ditentukan dalam undang-undang perlindungan anak. Begitu pula agar tidak terjadi perbedaan pendapat mengenai batasan tugas guru dalam menjalankan pendidikan dan pengajaran, maka perlu adanya singkronisasi dan harmonisasi undang-undang sistem pendidikan nasional, undang-undang guru dan dosen, dan undang-undang perlindungan anak. 


\section{DAFTAR PUSTAKA}

Ardi, Minal. (2013). "Perlindungan Hukum Terhadap Guru di Pontianak (Studi tentang Implementasi Pasal 39 ayat (3) Undang-Undang Nomor 14 Tahun 2005 Tentang Guru dan Dosen", Jurnal Edukasi, Vol. 11. No. 2 Desember.

Ariawati, Ketut Novi. (2017). "Bagaimana Cara Menjadi Guru Profesional Dalam Menigkatkan Hasil Belajar Siswa Dan Memperbaiki Pendidikan di Indonesia”, ResearchGate, March.

Faisal. (2018). Akibat Hukum Ketiadaan Akta Ikrar Wakaf Atas Perwakafan Tanah, 3, (2), 143 153. https://doi.org/10.30596/dll.v3i2.3154.

Fajaruddin, (2014), "Perlindungan Hukum Terhadap Anak Korban Pornografi”, Varia Justicia, Vol. 10 No.2 Oktober.

Harun. (2016). "Perlindungan Hukum Profesi Guru Dalam Prespektif Hukum Positif”, Jurnal Law and Justice Vol. 1 No.1 Oktober

Komara, Endang. (2016). ”Perlindungan Profesi Guru di Indonesia”, Mimbar Pendidikan, 1 (2) September.

Kunandar. (2009). Guru Profesional Kurikulum Tingkat Satuan Pendidikan (KTSP) dan Sukses Dalam Sertifikasi Guru, Jakarta, Rajawali Perss.

Makalah Hakikat Pendidikan, (2016). WWW. Mediapustaka.com., Senin, 21 Oktober.

Manizar, Elly. (2016). "Peran Guru Sebagai Motivator Dalam Pembelajaran”, Tadrib, Vol. 1. No. 2. Desember.

Mansur, Mochamad. (2016) "Perlindungan Hukum terhadap Profesi Guru Dikaitkan dengan Undang-Undang Perlindungan Anak", Suara Bojonegoro, sabtu, 26 Nopember.

Mavianti, (2019), "Perbedaan Hasil Belajar Pada Mata Pelajaran Pendidikan Agama Islam (PAI) Berdasarkan Keaktifan Belajar Siswa Kelas X SMA Swasta Al-Hidayah Medan", Intiqad: Jurnal Agama dan Pendidikan Islam, Vol. 11, No.1, Juni.

Nurmala, Leni Dwi. (2018). "Perlindungan Hukum Terhadap Tenaga Pendidik", Gorontalo Law Review, Vol. 1- No. 1 -April.

Pasaribu, Asbin, (2017), "Implementasi Manajemen Berbasis Sekolah Dalam Pencapaian Tujuan Pendidikan Nasional di Madrasah", Jurnal Edu Tech,Vol. 3, No. 1

Pedoman Kerja Antara POLRI dan PGRI Nomor: B/53/XII/2012, Nomor: 1003/UM/PB/XX/2012 Tentang Mekanisme Penanganan Perkara Dan Pengamanan Terhadap Profesi Guru.

Peraturan Pemerintah Nomor 19 Tahun 2017 Tentang Perubahan Atas Peraturan Pemerintah Nomor 74 tahun 2008 Tentang Guru

Ramadhani, Rahmat. (2017). Jaminan Kepastian Hukum Yang Terkandung Dalam Sertipikat Hak Atas Tanah, 2, (1), 139-157. https://doi.org/10.30596/dll.v2i1.1144

Ramlan. (2018). Perlindungan Hukum Bagi Guru dari Tindakan Semena-Mena badan/Pejabat Tata Usaha Negara, Kupulan Jurnal Dosen Universitas Muhammadiyah Sumatera Utara, 14 Agustus. 
Saat, Sulaiman. (2015). "Faktor-Faktor Determinan Dalam Pendidikan (Studi Makna dan Kedudukannya dalam Pendidikan)”, Jurnal Al-Ta'dib, Vol. 8 No. 2, Juli - Desember.

Sahbir, U.M. (2015). "Kedudukan Guru Sebagai Pendidik (Tugas dan Tanggungjawab, hak dan kewajiban, dan Kompetensi Guru", Auladuna, Vol.2 No. 2 Desember

Soekanto, Soerjono. (1986), Pengantar Penelitian Hukum, Jakarta, Universitas Indonesia Press. Sudirman. (2008). Interaksi dan Motivasi Belajar Mengajar. Jakarta, RajaGrafindo Persada.

Sukiman. (2016). "84 Persen Siswa Indonesia Alami Kekerasan di Sekolah", Kompas.Com. Selasa, 29 November: 16:00 Wib

Undang-Undang Nomor 14 Tahun 2005 Tentang Guru dan Dosen

Undang-Undang Nomor 20 Tahun 2003 Tentang Sistem Pendidikan Nasional

Undang-Undang Nomor 35 Tahun 2014 Tentang Perubahan Atas Undang-Undang Nomor 23 Tahun 2002 Tentang Perlindungan Anak

Uno, Hamzah B. (2009). Profesi Kependidikan, Problema, Solusi dan Reformasi Pendidikan di Indonesia. Jakarta, Bumi Aksara.

Winkel. (2005). Psikologi Pengajaran. Jakarta. Gramedia Pustaka.

Yusutria. (2017). "Profesionalisme Guru Dalam Meningkatkan Kualitas Sumber Daya Manusia”, Jurnal Curricular, Vol. 2 No, 2. 